\title{
KONDISI DAN STRUKTUR TERUMBU KARANG DI PERAIRAN BARAT SULAWESI SELATAN
}

\author{
Karsono Wagiyo*", Suprapto*) dan Hasan Mubarak*)
}

\begin{abstract}
ABSTRAK
Perairan barat Sulawesi Selatan memiliki berbagai tipe terumbu karang dengan keanekaragaman biotanya yang tinggi. Perkembangan daerah ini sangat dinamis sesuai dengan makin beragamnya aktivitas masyarakat. Kegiatan tersebut dikhawatirkan akan mempengaruhi kondisi dan struktur terumbu karang yang ada.

Untuk mengetahui kondisi terumbu karang di perairan barat Sulawesi Selatan telah dilakukan observasi dengan sensus visual pada garis transek di sepuluh lokasi terpilih secara cluster-stratified random sampling. Kriteria dari kondisi terumbu karang didasarkan pada penutupan karang hidup. Hasil penelitian menunjukkan bahwa tujuh lokasi telah rusak dan tiga lokasi dalam keadaan kritis. Terumbu karang terdiri atas karang mati, karang lunak dan karang otak.

Berdasarkan hasil penelitian tersebut dapat ditarik kesimpulan bahwa terumbu karang di perairan barat Sulawesi Selatan telah mengalami degradasi dan perlu dilakukan rehabilitasi. Untuk melibatkan masyarakat setempat dalam pengelolaun terumbu karang diperlukan pembinaan yang mengarah pada pengelolaan terumbu karang secara komunitas lokal.
\end{abstract}

ABSTRACT: Structure and condition of coral reefs in Western of South Sulawesi waters. By: Karsono Wagiyo, Suprapto and Hasan Mubarak.

The western part of South Sulawesi waters have several types of coral reefs with high biodiversity. This area develops dynamically as the economic activities of the community increase. Those activities influence the structure and condition of coral reefs. The research on coral reefs condition in west of South Sulawesi waters has been rarried out by using visual census and transect method in ten locations. Sampling was performed by employing cluster-stratified random sampling. Criterion of the coral refs condition was based on living coral coverage.

Results of the resectrch indicated that there were senen locations that have damaged and three. locations in critical condition. The coral reefs consist of dead, soft and massine coral.

It could be concluded that coral reefs degradation has occurred in the west part of South Sulawesi waters and rehabilitation is needed immediately. For this purpose, the coral reef management should be based on the participation of local communities.

KEYWORDS: coral reefs, bio-diversity, South Sulawesi waters.

\section{PENDAHULUAN}

Perairan barat Sulawesi Selatan merupakan daerah peralihan flora dan fauna antara benua Asia dengan Australia dan antara Samudera Pasifik dengan Samudera India. Daerah ini memiliki berbagai tipe terumbu karang seperti terumbu karang pelindung, terumbu karang tepi dan terumbu karang atol (Whitten et al., 1987), Sumber daya hayati ikan yang terkenal di perair- an ini antara lain ikan kerapu, teripang dan moluska (Erdmann, 1995).

Keanekaragaman sumber daya tersebut menyebabkan kawasan terumbu karangnya menarik minat berbagai pihak untuk melakukan eksploitasi baik oleh penduduk setempat maupun dari luar kawasan. Nelayan perairan barat Sulawesi Selatan, sebagaimana nelayan pada umumnya sangat tergantung dari sumber daya laut. Berbagai jalan mereka tempuh untuk memanfaatkan

Peneliti pada Balai Penelitian Perikanan Laut 
sumber daya terumbu karang yang kadangkadang dilakukan secara ilegal seperti penggunaan bom dan garam sianida. Akibat kegiatan tersebut sebagian besar terumbu karangnya telah mengalami kerusakan. Keadaan ini mirip dengan yang terjadi di Filipina bahwa pemboman dan penggunaan garam sianida adalah dua faktor utama penyebab kerusakan terumbu karang (McManus et al.,1992). Kerusakan ini dikhawatirkan akan terus berlanjut dan bertambah sejalan dengan keterbukaan kawasan ini sebagai jalur pelayaran internasional. Selain itu degradasi terumbu karang di sini makin meluas oleh kegiatan konversi lahan pesisir untuk berbagai kepentingan.

Monitoring kondisi terumbu karang sangat penting sebagai bahan evaluasi dan penyusunan kebijaksanaan pembangunan wilayah pesisir yang berwawasan lingkungan.

Dengan mengetahui kondisi dan struktur terumbu karang yang ada pada saat ini dapat ditentukan langkah-langkah dan cara-cara pemanfaatan, konservasi dan rehabilitasi untuk memulihkan sumber daya yang ada.

\section{BAHAN DAN METODE}

Penelitian dilakukan pada bulan Desember 1994 di perairan terumbu karang di barat Sulawesi Selatan. Pemilihan stasiun sampel dilakukan secara cluster - stratified random sampling. Lokasi terpilih meliputi perairan Takalar (tiga stasiun), Pangkajene Kepulauan atau Pangkep (dua stasiun), Barru (dua stasiun) dan Poliwali Mamassa atau Polmas tiga stasiun (Gambar 1). Pengelompokan (clustering) berdasarkan pada lokasi spesifik yang diperkirakan mewakili terumbu karang di perairan barat Sulawesi Selatan. Sedangkan stratifikasi berdasarkan pada perkiraan tingkatan kondisi terumbu karang. Pada tujuh stasiun yaitu Punaba, Laikang, P. Tanakeke (Takalar), P.Panambungan, P. Cangkee (Pangkep), P. Bhaki (Barru) dan Tomapangka (Polmas) dibuat transek memanjang tegak lurus garis pantai sampai dengan kedalaman akhir dari pertumbuhan terumbu karang (modifikasi dari Mulyanto, 1986). Sedang pada tiga stasiun yaitu Tanjung Kupa (Barru), P. Batowae dan P. Gosong (Polmas) dilakukan metode manta tow yaitu snorkeling dengan ditarik perahu di permukaan air untuk memperkirakan tutupan karang hidup.
Penggunaan manta tow pada ketiga stasiun tersebut dilakukan dengan pertimbangan bahwa struktur terumbu karangnya sama dengan stasiun lainnya pada lokasi yang sama, meliput daerah yang luas dan tidak mengamati tipe pertumbuhan karang karena keterbatasan waktu dan tenaga.

Pengamatan kondisi terumbu karang secara visual di dalam dengan mengukur tutupan terumbu karang hidup di sepanjang garis transek. Jarak pengamatan dari garis transek ke kanan 2,5 m dan ke kiri 2,5 m. Kriteria kondisi terumbu karang didasarkan pada persentase penutupan terumbu karang hidup menurut Gomez \& Yap (1984) yang dikelompokkan menjadi empat golongan yaitu: kritis $(0,0 \%-24,9 \%)$; rusak $(25 \%$ $49,9 \%$ ); baik (50\%-74,9\%); dan madani ( $75 \%$ 100\%). Pengelompokan tipe pertumbuhan karang mengikuti English et al. (1994).

\section{HASIL DAN PEMBAHASAN}

\section{Kondisi Terumbu Karang}

Hasil penelitian menunjukkan bahwa kondisi terumbu karang di perairan barat Sulawesi Selatan (selain Pulau Kapoposan) dalam kondisi kritis dan rusak atau dengan rata-rata tutupan karang hidup hanya 27,8\% (Tabel 1). Tutupan karang hidup terendah yaitu antara 10\%-25\% dijumpai pada stasiun dekat pantai yaitu Punaba, Laikang dan Pulau Bhaki. Sedangkan pada stasiun yang jauh dari pantai seperti yang dijumpai di Pulau Panambungan dan Pulau Cangkee tutupan karang hidupnya cukup tinggi yaitu antara $34,27 \%-49,54 \%$. Hasil ini sama dengan penelitian Kunzman \& Effendie (1994) di perairan Sumatera Barat.

Keadaan tersebut di atas disebabkan terumbu karang dekat pantai mendapat tekanan dari aktivitas manusia yang lebih intensif berupa pemboman, penambangan, penggunaan garam sianida serta sedimentasi sebagai akibat dari rusaknya sistem penyangga hutan bakau. Kerusakan hutan bakau tersebut disebabkan adanya kegiatan konversi untuk tambak (Whitten et al., 1987). Kondisi tutupan karang hidup yang demikian rendah menunjukkan kerusakan terumbu karang di kawasan perairan pantai barat Sulawesi Selatan menuju pada tingkat 
kerusakan yang permanen (tidak dapat dipulihkan). Kondisi demikian dapat menyebabkan hilangnya sumber daya perikanan. Hal ini didukung oleh hasil penelitian Wagiyo \& Prahoro (1994) di perairan Karimunjawa bahwa penurunan kondisi terumbu karang dari sangat baik (penutupannya $75 \%-100 \%$ ) ke kondisi rusak (penutupannya $25 \%-49,9 \%$ ) menyebabkan penurunan kepadatan ikan sebesar $61 \%$.
Untuk mencegah kerusakan lebih lanjut dan memulihkan sumber daya yang ada, diperlukan suatu tindakan konservasi dan rehabilitasi dengan mengikutsertakan masyarakat setempat dalam pengelolaannya. Tindakan ini dapat be. rupa pemasangan terumbu buatan, transplantasi karang, rehabilitasi ekosistem terkait (padang lamun dan hutan bakau) serta perbaikan kondisi biofisik di pantai.

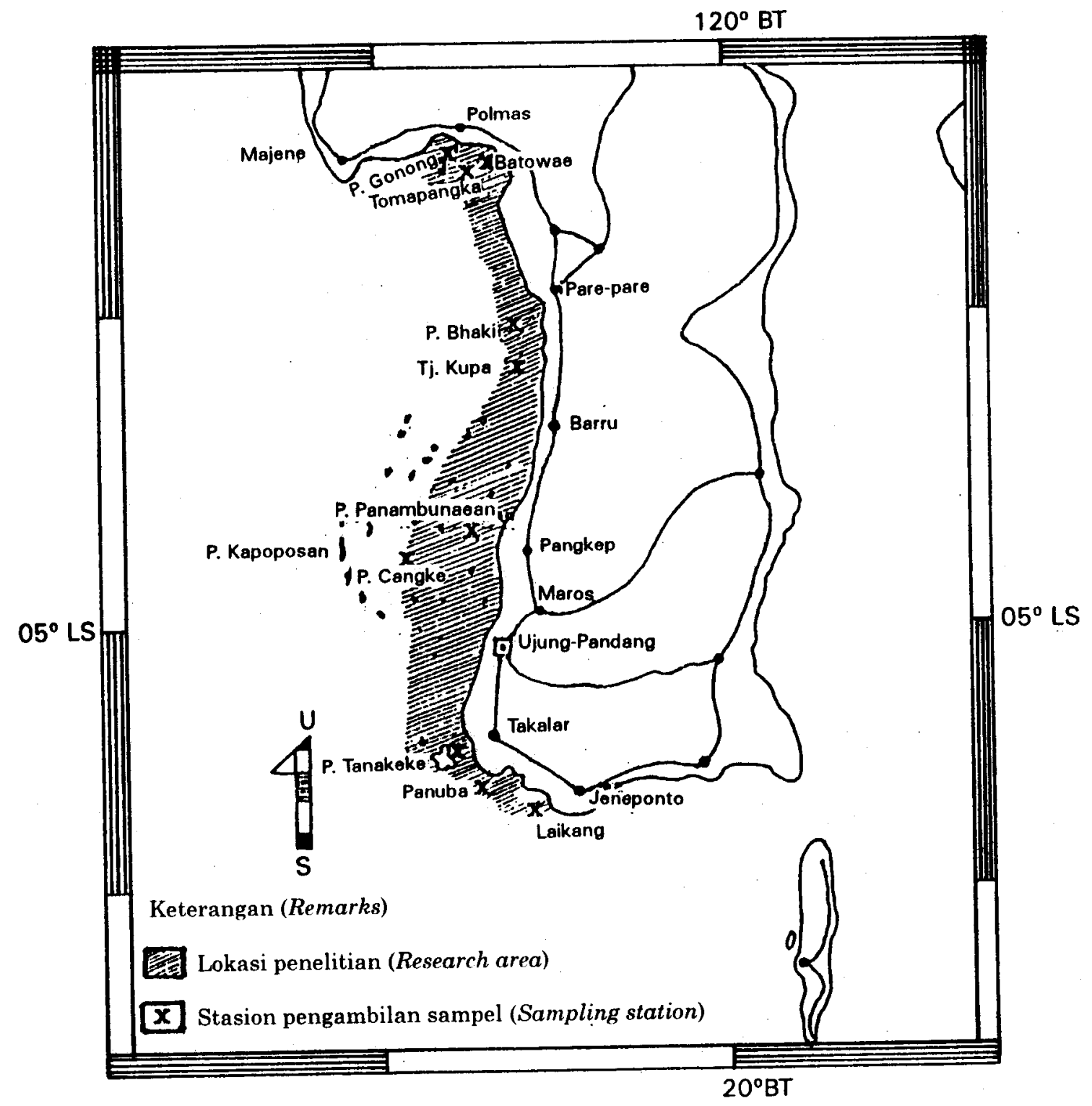

Gambar 1. Peta lokasi penelitian.

Figure 1. Map of research area. 
Wagiyo, K.; Suprapto dan H. Mubarak

Tabel 1. Kondisi dan tutupan karang hidup di perairan barat Sulawesi Selatan.

Table 1. Condition and coverage of coral reefs in western part of South Sulawesi waters

\begin{tabular}{|c|c|c|}
\hline $\begin{array}{c}\text { Lokasi } \\
\text { Location }\end{array}$ & $\begin{array}{c}\text { Penutupan }(\%) \\
\text { Coverage }(\%)\end{array}$ & $\begin{array}{c}\text { Kondisi } \\
\text { Condition }\end{array}$ \\
\hline \multicolumn{3}{|c|}{ Kabupaten Takalar (Takalar Regency) } \\
\hline - Punaba & 25.00 & kritis (critical) \\
\hline - Laikang & 25.00 & kritis (critical) \\
\hline - Tanakeke & 29.20 & rusak (damaged) \\
\hline \multicolumn{3}{|l|}{$\begin{array}{l}\text { Kabupaten Pangkajene (Pangkajene } \\
\text { Regency) }\end{array}$} \\
\hline - Panambungan & 49.54 & rusak (damaged) \\
\hline - Cangkee & 34.27 & rusak (damaged) \\
\hline \multicolumn{3}{|l|}{ Kabupaten Barru (Barru Regency) } \\
\hline - P. Bhaki & 10.00 & kritis (critical) \\
\hline - Tanjung Kupa & 25.30 & rusak (damaged) \\
\hline \multicolumn{3}{|c|}{ Kabupaten Polmas (Polmas Regency) } \\
\hline - Tomapangka & 35.80 & rusak (damaged) \\
\hline - P.Gosong & 15.97 & kritis (critical) \\
\hline - Batowae & 25.30 & rusak (damaged) \\
\hline $\begin{array}{l}\text { Rata-rata persentase penutupan } \\
\text { Average of percent coverage }\end{array}$ & 27.8 & rusak (damaged) \\
\hline
\end{tabular}

\section{Struktur Terumbu Karang}

Struktur terumbu karang di perairan barat Sulawesi Selatan terdiri dari karang mati (dead coral), karang lunak (soft coral) dan karang otak (massive coral). Rata-rata penutupannya pada berbagai lokasi adalah $36,03 \% ; 13,40 \%$ dan $8,20 \%$ (Tabel 2)

Tipe-tipe penutupan coral seperti di atas menunjukkan bahwa terumbu karang di perairan barat Sulawesi Selatan telah mengalami kerusakan akibat aktivitas manusia. Pada terumbu karang alami dan rusak yang disebabkan oleh peristiwa alam, pertumbuhan karang tipe bercabang dominan. Hal ini didukung oleh pengamatan Wijsman-Best (1977) yang mendapatkan bahwa terumbu karang di perairan Sulawesi didominasi oleh pertumbuhan karang bercabang (branching). Penelitian di lokasi lain yang masih alami adalah di perairan Pulau Seram di mana didapatkan karang bercabang dominan (Hurasan et al., 1992). Pada kedua lokasi ini, kondisi terumbu karangnya masih baik dan belum banyak mendapat pengaruh aktivitas manusia. Penelitian oleh Moll (1985) dalam Whitten et al. (1987) pada terumbu karang alami di Takabonerate menunjukkan bahwa pertumbuhan karang bercabang mempunyai persentase penutupan yang lebih besar dari tipe karang mati dan karang lunak (Tabel 3). Berdasarkan hasil dari ketiga penelitian tersebut, diduga bahwa struktur terumbu karang di perairan barat Sulawesi Selatan merupakan hasil proses kerusakan karena ulah manusia.

Karang mati sebagai indikator kerusakan terumbu karang mengacu pada prinsip pertumbuhan binatang karang yang tidak terbatas oleh waktu. Pada keadaan perairan dengan toleransi optimum bagi kehidupan, binatang karang akan tumbuh'terus. Kematian biota karang biasanya disebabkan oleh pencemar atau akibat ekploitasi sumber daya yang tidak rasional. 
Tabel 2. Struktur dan persentase penutupan dari pertumbuhan benthos pada terumbu karang di perairan barat Sulawesi Selatan.

Table 2. Structure and percentage coverage of growth type benthic organism on coral reefs in western part of South Sulawesi waters.

\begin{tabular}{|c|c|c|c|c|c|c|c|c|c|}
\hline $\begin{array}{c}\text { Tipe karang } \\
\text { Coral type }\end{array}$ & 1 & 2 & 3 & 4 & 5 & 6 & 7 & $\begin{array}{c}\text { Jumlah } \\
\text { Total } \\
\end{array}$ & $\begin{array}{c}\text { Rata-rata } \\
\text { Average }\end{array}$ \\
\hline Massive structure & & & & & & & & & 3.25 \\
\hline $\begin{array}{l}\text { Non massive } \\
\text { Acropora }\end{array}$ & 4.20 & 13.30 & 11.60 & 12.10 & 13.94 & 0.40 & 1.90 & 57.44 & 8.20 \\
\hline - Acropora massive & 0.00 & 0.00 & 0.00 & 0.00 & 0.00 & 0.10 & 0.00 & 0.10 & 0.01 \\
\hline $\begin{array}{l}\text { Acropora } \\
\text { submassive }\end{array}$ & 0.00 & 12.30 & 0.00 & 1.00 & 0.00 & 0.30 & 1.80 & 15.40 & 2.20 \\
\hline - Coral submassive & 0.00 & 0.00 & 1.90 & 1.20 & 1.40 & 0.23 & 6.40 & 11.13 & 2.59 \\
\hline Branching structure & & & & & & & & & 1.76 \\
\hline - Coral branching & 0.00 & 0.00 & 0.00 & 7.70 & 0.00 & 1.12 & 6.40 & 15.22 & 2.17 \\
\hline - Acropora branching & 0.00 & 0.30 & 6.50 & 19.90 & 12.94 & 0.90 & 9.60 & 50.14 & 7.16 \\
\hline - Coral encrusting & 0.00 & 0.00 & 6.20 & 1.50 & 0.00 & 0.00 & 0.00 & 7.70 & 1.00 \\
\hline - Acropora digitate & 0.00 & 0.00 & 0.00 & 0.90 & 1.79 & 0.00 & 2.00 & 4.69 & 0.66 \\
\hline - Coral millepora & 0.00 & 0.00 & 0.00 & 1.30 & 2.39 & 0.00 & $0 . \Theta 0$ & 3.69 & 0.53 \\
\hline Acropora tabulate & 0.00 & 0.00 & 0.00 & 0.50 & 0.00 & 0.00 & 3.00 & 3.50 & 0.50 \\
\hline Acropora encrusting & 0.00 & 0.00 & 0.00 & 1.50 & 0.00 & 0.00 & 0.80 & 2.30 & 0.33 \\
\hline Folious & 11.00 & 0.00 & 1.50 & 1.90 & 0.00 & 0.00 & 0.00 & 14.40 & 2.06 \\
\hline Mushroom & 0.00 & 1.80 & 0.00 & 0.00 & 0.00 & 0.00 & 0.00 & 1.80 & 0.26 \\
\hline Soft coral & 36.80 & 3.70 & 5.70 & 8.90 & 2.40 & 1.20 & 35.00 & 94.10 & 13.40 \\
\hline Turf coral & 13.70 & 24.10 & 0.70 & 0.30 & 1.60 & 0.00 & 0.00 & 40.40 & 5.77 \\
\hline Others & 1.70 & 4.40 & 0.70 & 4.57 & 0.19 & 0.05 & 1.60 & 13.21 & 1.87 \\
\hline Dead coral & 0.00 & 30.5 & 35.60 & 32.80 & 37.45 & 92.50 & 23.40 & 252.00 & 36.03 \\
\hline Sponge & 0.00 & 1.60 & 0.00 & 0.00 & 0.00 & 0.00 & 0.00 & 1.60 & 0.23 \\
\hline Sand & 32.60 & 6.20 & 29.60 & 4.01 & 25.90 & 3.20 & 5.40 & 106.90 & 15.27 \\
\hline Ruble & 0.00 & 1.80 & 0.00 & 0.00 & 0.00 & 0.00 & 0.00 & 1.80 & 0.25 \\
\hline Zoanthid & 0.00 & 0.00 & 0.00 & 0.00 & 0.00 & 0.00 & 2.30 & 2.30 & 0.33 \\
\hline Total & 100.00 & 100.00 & 100.00 & 100.00 & 100.00 & 100.00 & 100.00 & 700.00 & \\
\hline
\end{tabular}

Keterangan (Remarks): $\quad$ 1. Punaba $\quad$ 2. Laikang $\quad$ 3. P. Tanakeke $\quad 4$. P. Panambungan 5. P. Cangkee 6. P. Bhaki 7. Tomapangka

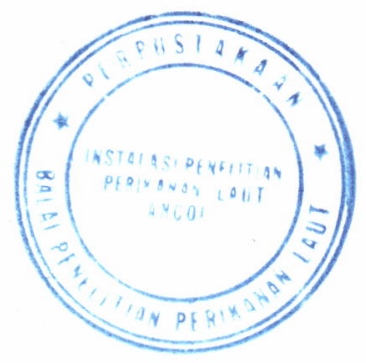


Tabel 3. Stuktur terumbu karang alami di Takabonerate. Table 3. Structure of natural coral reefs at Takabonerate.

\begin{tabular}{cccc}
\hline \multirow{2}{*}{$\begin{array}{c}\text { No. pengamatan } \\
\text { No. of observation }\end{array}$} & \multicolumn{3}{c}{ Peresentase penutupan (Percent coverage) } \\
\cline { 2 - 4 } & $\begin{array}{c}\text { Karang bercabang } \\
\text { Branching coral }\end{array}$ & $\begin{array}{c}\text { Karang folik } \\
\text { Folious coral }\end{array}$ & $\begin{array}{c}\text { Karang otak } \\
\text { Massive coral }\end{array}$ \\
\hline 1 & 53 & 11 & 26 \\
2 & 52 & 0 & 45 \\
3 & 54 & 7 & 37 \\
4 & 58 & 38 & 0 \\
\hline
\end{tabular}

Sumber (Source): Whitten et al. (1987)

Setiap pencemaran oleh manusia menyebabkan ciri khas pada kematian binatang karang. Menurut Subani (1983) ciri khas akibat penggunaan bahan peledak adalah terjadinya kehancuran binatang karang yang berkepingkeping. Binatang karang yang mati akibat pencemaran sedimen, tubuhnya tetap utuh dengan permukaannya diseliputi oleh partikel-partikel. Kematian binatang karang karena teracuni garam sianida, tubuhnya masih utuh dan bersih dari partikel tetapi nampak tidak cerah (pucat).

Karang lunak digunakan sebagai indikator kerusakan terumbu karang karena ulah manusia berdasarkan pada pertumbuhannya yang lebih cepat dan mudah menggunakan berbagai substrat yang mati (Barnes \& Hughes,1989). Pertumbuhan yang lebih cepat dan mudah ini pada suatu tempat yang struktur terumbu karangnya telah rusak akan menutup kesempatan bagi pertumbuhan binatang karang hermatipik. Pada terumbu karang yang rusak karena gejala alam, pemulihan kembali (recovery) antara karang lunak dan karang hermatipik akan berjalan secara bersama. Dalam hal ini karang hermatipik tidak kalah bersaing dengan karang lunak, sehingga terumbu karang yang baru pulih dari kerusakan strukturnya tidak didominasi oleh karang lunak. Sedangkan persentase penutupan pertumbuhan karang otak yang relatif besar dapat dipakai sebagai indikasi adanya kerusakan terumbu karang yang disebabkan. oleh pertumbuhannya yang relatif resisten terhadap pengaruh pencemar (ulah manusia). Sebagai contoh pada kasus penggunaan bahan peledak, karang otak akan lebih tahan dari kehancuran dibandingkan dengan karang bercabang. Karang otak juga lebih tahan terhadap pengaruh endapan sedimen (Jeffrey \& Chan 1994).

\section{KESIMPULAN DAN SARAN}

1. Kondisi terumbu karang di perairan barat Sulawesi Selatan berada dalam keadaan rusak dengan rata-rata penutupan binatang karang hanya $27,8 \%$.

2. Struktur terumbu karang di perairan barat Sulawesi Selatan ditandai oleh tingginya penutupan karang mati $(36,03 \%)$, karang lunak $(13,40 \%)$ dan karang otak $(8,20 \%)$ serta rendahnya penutupan karang bercabang $(1,76 \%)$. Ini menunjukkan bahwa kerusakan terjadi karena aktivitas manusia antara lain penggunaan bahan peledak, garam sianida dan sedimentasi.

3. Mengingat sebagian besar kondisi terumbu karang di perairan barat Sulawesi Selatan sudah kritis dan rusak, disarankan untuk memulihkan kembali kondisinya dengan konservasi dan rehabilitasi melalui transplantasi karang, terumbu buatan dan rehabilitasi ekosistem terkait.

4. Selain itu supaya usaha penanggulangan kerusakan terumbu karang berhasil maka disarankan dalam pengelolaannya sebaiknya mengikutkan masyarakat setempat sebagai komponen inti (local community based management). 


\section{DAFTAR PUSTAKA}

Barnes. R.S.K. and R.N. Hughes. 1989. An introduction to marine ecology. Second Edition. Melbourne

Erdmann. 1995. An ABC Guide to coral reef fisheries in Southwest Sulawesi, Indonesia. NAGA.The ICLARM Quarterly. April 1995. 4-6.

Gomez E.D. and Yap. H. 1984. Monitoring reef condition. In: Coral Reef Management Handbook. R.A. Kenchington and E.T.Hudson (eds). Unesco. 171.178

Jeffrey K.Y.L. and I.M. Chan. 1994. Coral reef fish community in a sediment stressed environment. Proceedings. Fourth UPI JSPS fourt Seminur on Marine Science. Jakarta, 15-18 Nov. 91-99

Kunzmann, A. dan Y. Effendie. 1994. Kerusakan terumbu Karang di perairan sepanjang pantai Sumatera Barat. Jurnal Penelitian Perikanan Laut. No. 91; Jakarta. 48-56.

Hurasan M.S., Malawat S. dan Zubaidi T. 1992. Studi ikan hias laut dan terumbu karang di sekitar perairan Seram Barat. Jurnal Penelitian Perikan. an Laut No. 70. Balai Penelitian Perikanan Laut. Jakarta. 97-104
McManus J.W., C.L. Nanola, R.R. Reyes Jr., K.N Kesner. 1992. Resource ecology of the Bolinao coral reef system. NAGA. ICLARM 15(3):43-45.

Mulyanto. 1986. Pemanfautan terumbu karang, metode pendugaan dan pengelolaannya di negara. negara ASEAN. Direktorat Jenderal Perikunan dan International Development Research Centre.

Subani. W. 1983. Studi mengenai efek-efek negatif penggunaan bahan peledak untuk penangkapan ikan. Laporan Penelitian Perikanan Laut No.26. Balai Penelitian Perikanan Laut. Jakarta 1-20.

UNEP. 1993. Monitoring coral reefs for global change. Reference methods for marine pollution studies No.61. United Nations Environment Programme 25-39.

Wagiyo, K. dan P. Prahoro. 1994. Pengaruh kondisi terumbu karang terhadap komunitas ikan hias di Kep. Karimunjawa. Jurnal Penelitian Perikanan Laut No. 92. Balai Penelitian Perikanan Laut. Jakarta. 27-36

Whitten A.S., M. Mustafa, G.S. Henderson. 1987. The ecology of Sulawesi. Gadjah Mada University Press. 227.

Wijsman, M. - Best. 1977. Coral research in the Indonesian archipelago, the past, the present, and the future. Marine Research in Indonesia No.17. 1-14. 